\title{
The Common Good of the Firm in the Aristotelian-Thomistic Tradition
}

\author{
Alejo José G. Sison \\ Joan Fontrodona \\ University of Navarre
}

\begin{abstract}
This article proposes a theory of the firm based on the common good. It clarifies the meaning of the term "common good" tracing its historical development. Next, an analogous sense applicable to the firm is derived from its original context in political theory. Put simply, the common good of the firm is the production of goods and services needed for flourishing, in which different members participate through work. This is linked to the political common good through subsidiarity. Lastly, implications and challenges arising from the positing of work as the common good of the firm are explored.
\end{abstract}

KEY WORDS: virtue, common good, business ethics, theory of the firm, justice

\section{INTRODUCTION}

$\mathrm{M}$ UCH POPULAR AND ACADEMIC DISCUSSION OF ETHICS, including business ethics, invokes the idea of the common good (de Bettignies, 2009; Deissenberg \& Alvarez González, 2002; Hesselbein, 2008; Holzinger, 2003; Lewis, 2006; Lindahl \& Johannesson, 2009; Machan, 1993; Urban, 2007; Van der Wal \&Van Hout 2009). But as Hayek has noted regarding the "common good" and similar terms such as "general welfare" and "general interest," "it does not need much reflection to see that these terms have no sufficiently definite meaning to determine a particular course of action" (Hayek, 2001: 60). Moreover, when the "common good" is given some degree of specificity, it often is in ways that reduce this idea to what is more individualistic rather than truly common, such as aggregate social utility, or a collection of essentially individual rights, or the contractual agreements among individuals participating in some kind of social choice situation or other deliberative endeavor. In short, conventional thinking seems too often to either dismiss the idea of a common good, or reduce it to notions that are more easily parsed in terms of the dominant, broadly individualist and non-teleological framework of Western moral philosophy.

In this article we take a very different approach. Specifically, we draw from three related schools of thought-Aristotelian ethics, Thomistic ethics and Catholic Social Thought (henceforth, CST) — that explicitly speak in terms of an idea of the

This submission to the special issue was managed by former editor in chief and current senior associate editor Gary Weaver. 
common good. These frameworks typically address questions that arise in societal contexts (e.g., Aristotle's concern for the polis, literally, the "city," understood as the political community), or in the world of individual thought and action (e.g., matters of virtue and happiness). But from these three streams of thought we build a conception of the common good specifically of a firm, that is, something that is less encompassing than an entire polis or political community, but larger and more encompassing than individuals and families. Firms, therefore, are viewed as some kind of intermediate body or organization situated between individuals and families, on the one hand, and the political community, on the other.

From Aristotle we borrow a general conception of the common good defined in terms of eudaimonia or human flourishing and grounded on his understanding of the polis. From Aquinas we adapt an analogical way of thinking of the common good that renders it applicable not only to the polis but to other entities as well, including families and God. And from CST we borrow a multi-level way of thinking about the contributions to the common good from multiple, historically situated actors (e.g., individuals, organizations such as firms, and states). Together, these approaches enable us to delineate a view of the common good of the firm. Having located the firm as an intermediate entity, we define its common good-by analogy with the common good of the political community - as the production of goods and services necessary for human flourishing. But as articulated in our theory of the common good of the firm, this productive work ought to be understood above all as a human activity whose internal results or subjective dimensions (such as knowledge or skills acquired, habits and virtues developed, meaning) take precedence over the external results or objective dimensions (such as the goods and services in themselves, or profits earned). The common good of the firm is the work in common that allows human beings not only to produce goods and services (the objective dimension), but more importantly, to develop technical or artistic skills and intellectual and moral virtues (the subjective dimension). This theory of the common good of the firm, in turn, helps us understand how work, profits, virtue, a firm's purpose, personal flourishing in the polis and belief in God are articulated in ways that more conventional business ethics theories, rooted in the broad tradition of post-Enlightenment moral philosophy, cannot.

We think that such a discussion of the common good of the firm can contribute to the virtue theory approach to business ethics in several ways. Firstly, it identifies virtue in general with the subjective, non-material dimension of the common good of the firm. Secondly, it underscores virtue's dominant and teleologically superior position with regard to the objective and material elements of the common good of the firm. Although it may prove extremely difficult to cultivate virtue without quality products and services and profits (objective dimension), these would amount to almost nothing, from the human and ethical perspective, if they were produced in contempt of virtue (subjective dimension). From the Aristotelian, Thomistic and CST standpoints, in the same way that, without virtue, flourishing would not be possible in the political community, without virtue, neither would flourishing be possible in the firm. Virtue is key. Thirdly, specific virtues are required of the different stakeholders that participate in the common good of the firm through their work, 
in a similar manner that particular virtues are expected from the different citizens who take part in the public action that constitutes their flourishing. Unfortunately, we won't be able to deal with this in detail. Our intent lies more in raising the possibility of these different groups participating at the same time in the subjective, virtuous dimension, aside from the objective, material dimension of the common good, albeit in diverse manners. Fourthly, we likewise wish to contribute to a more nuanced understanding of the virtue of justice, in its role of regulating and guiding the participation of the various stakeholder groups in the common good of the firm, by analogy to its orientational function among the many citizens who responsibly take part in the common good of the political community. In short, we would like to suggest several different ways in which virtue could fulfill its integrative potential with the common good theory as backdrop.

In what follows, we first briefly describe the core elements we borrow from Aristotle, Aquinas and CST. We begin with Aristotle's general account of the flourishing of a political community, then move on to Aquinas's analogical and theological expansion of the Aristotelian framework, and end with CST's application of the Aristotelian-Thomistic paradigm to specific social and historical settings (section 1). Once that preliminary explication is completed, we offer our general picture of the common good of the firm (section 2). We then contrast this view with more conventional thinking and offer an indication of how our approach helps raise and illumine important questions in business ethics (section 3). And we do this with the proviso that we are not offering here comprehensive defenses of Aristotelian, Thomistic, and CST, but rather exploring how a firm-specific theory of the common good can be built upon such foundations.

\section{THE COMMON GOOD OF THE POLITICAL COMMUNITY}

The premise is that every human group must have its own common good. We shall now examine the main sources of the theory of the common good in Aristotle, Aquinas and CST. We will present their positions largely as givens, interpretive controversies notwithstanding, because of constraints of time and space. That's why we'll use direct quotations as much as possible and leave commentary to a minimum. Although most of the texts we cite weren't written initially with business organizations in mind, nevertheless they will allow us later to articulate and explain an applicable version of the common good.

\section{Aristotle and the Common Good of the Polis}

In this subsection we shall consider the origins of the notions of the "good" and the "common good" in Aristotle, as well as the manner in which the members of the polity participate in it.

What is the "good"? In the Nicomachean Ethics (Aristotle, 1985; hereafter referred to as NE), Aristotle defines the good as "that at which everything aims" (NE 1094a), the end of an appetite, desire, inclination or tendency; that which satisfies them. What about the "common good"? It is the good of the polis, which is "finer and more divine" (NE 1094b) than individual goods. Besides common 
and individual goods, the Nicomachean Ethics contains yet another classification: goods pursued in themselves (e.g., eudaimonia or "happiness") and goods pursued because of another (e.g., money and other forms of wealth which are desired only insofar as they are useful or instrumental for other goods). Aristotle affirms that a good pursued in itself is better because it is complete, lacking nothing (NE 1097a). Among the goods pursued in themselves, eudaimonia or "happiness," a flourishing life, stands out as most choiceworthy, complete and self-sufficient (NE 1097b). This self-sufficiency, however, does not consist in living an isolated life, but in sharing a good life in common, with family, friends and fellow-citizens in the polis (NE 1097b). And not any polis would do, but only those under a just regime (Aristotle, 1988: 1279a-b; hereafter referred to as Pltcs). Eudaimonia, the common good of the polis, is also the supreme human good.

The common good which Aristotle proposes is concrete, contingent and specific to a polis; not the Platonic Idea of the Good (NE 1096a-b). As M. A. Smith suggests, "[T]he common good is the good of all members of a political community once these members have actualized their disposition to live in common. They organize themselves in view of the good which political life can provide them; they enjoy the advantages of life in common. And these advantages can vary from one period of time to another, and also from one place to another" (Smith, 1995: 63).

How do individuals in the polis participate in the common good? They share or take part in the common good through citizenship. For Aristotle, the polis is a whole made up of citizens, who are its parts (Pltcs 1274b). "A citizen in the strictest sense" is he who "shares in the administration of justice, and in offices" (Pltcs 1275a). Hence, the essential task of citizens is to decide on what is good and just in the polis. Although many people in a polis may actually participate in deliberating and deciding on the common good, only citizens do so by exercising a right, as a legally protected power (Pltcs 1275b). The common good results from the joint deliberation, decision and action of citizens.

In summary, for Aristotle, the common good is the good of the polis and of each citizen. Another name for it is eudaimonia, man's highest good. The common good of the polis allows us to distinguish just regimes from perverse ones. And the manner in which human beings participate in eudaimonia is through citizenship.

\section{Aquinas on God as the Common Good}

What modifications does Aquinas introduce to Aristotle's understanding of the common good? As a Christian philosopher, Aquinas is obliged to account for the relation between God and human flourishing in the polity. He achieves this by devising an analogy of the common good that respects its fundamental nature, as the good of the whole and of each part (Froelich, 1989: 42). Analogy means using a term partly in a similar, partly in a different way. For instance, we could use the term "body" to refer to an organism or to a human community. Both are composed of members or parts functioning as one, although one is a biological entity and the other, a social entity. Aquinas's purpose, therefore, is to introduce God in the Aristotelian notion of the common good and he makes use of analogy as his tool. 
In a treatise on the spiritual life, Aquinas writes: "in this community by which all people agree on happiness as an end, each and every man is considered as a certain part: but the common good of the whole is God himself, in whom consists the happiness of all" (Aquinas, 1954: 634). For Aquinas, God as the Supreme Being is not only the common end of every human being and of the whole species, but also, the ultimate cause of all good. Moreover, God is likened to the happiness which all people in the community seek.

In Aquinas, an analogy of proportionality exists between God, as major analogue, and other common goods such as eudaimonia, as minor analogues (Smith, 1995: 72-74). As we have seen earlier in Aristotle, the "good" refers to an end or perfection of a nature. The "common good" then indicates a common end or perfection, in this case, of human beings. God may be considered an extrinsic, ontological and speculative common good, and eudaimonia, an intrinsic, social and practical common good. As a common good God is "extrinsic," because he exists separately from the universe, "ontological" because he is a being unto himself, not a mere unity of order, and "speculative" because he is an object of contemplation, not production. Eudaimonia, on the other hand, is "intrinsic," because it does not exist apart from the political community, "social" because the polity is a mere unity of order, not of being, and "practical" because it is an object of production, not of contemplation. For Aquinas the contemplation of God is the supreme human good and basis of political eudaimonia.

Eudaimonia or the political common good, in turn, is an "integral whole" (Aquinas, 1993: I, 1, 11; Walshe, 2006: 215-34) consisting of several kinds of parts. We may distinguish between "formal" and "material" parts, on the one hand, and "actual" and "potential" parts, on the other. A "formal" part is a good that does not diminish despite being participated in by many, while a "material" part is a good that diminishes when distributed among many. Similarly, an "actual" part is one that is unique, not admitting replacement or substitution, while a "potential" part is replaceable or substitutable. Knowledge, for example, is both a "formal" and an "actual" part of eudaimonia: "formal," because one person's knowledge does not detract nor diminish the possibility of another person possessing that same knowledge, and "actual," because each kind of knowledge is unique, and could not be replaced by any other. Knowledge, therefore, does not diminish as the number of people who possess it increases; on the contrary, it becomes even greater when shared. Knowledge is what is known in modern economic theory as a "public good" or a "collective consumption good," characterized by nonrivalrous and nonexcludable consumption (Samuelson, 1954). Although public goods share some characteristics with the common good, such as not being zero-sum (Smith, 1999), however, they are not identical. Unlike public goods, the common good admits no free-riders, and each party's actual contribution is essential to the realization of the good in the first place.

In like manner, water is an example of both a "material" and "potential" part of eudaimonia: "material" because the water that one drinks can no longer be drank by any other, and "potential," because any quantity of water used for drinking can be replaced by another of similar characteristics. Moreover, water is only potentially part of the common good while stored in the reservoir, because actually, any 
discrete amount could be used for drinking only by one person at a time. Thus we understand that water is an instance of the bona communia (Aquinas, 1962: I, 7, 95), the means or instruments for the preservation of eudaimonia, whose partitioning among the members of the polity should be carried out in accordance with the principles of distributive justice.

The analogy of the common good in Aquinas allows for the term's usage in other contexts aside from eudaimonia in the polis. The common good could also refer to God as the highest object of contemplation, but not only for an elite, as in the Aristotelian polis, but also for every human being. Similarly, in the family, we could speak of children as the common good of spouses (Smith, 1995: 76; Walshe, 2006: 242). Husband and wife come together for the purpose of begetting and educating children. Each child is a good for the father only insofar as it is also a good for the mother, and a child's being a good for either parent is inseparable from its being a good for both. Neither parent can beget a child alone; yet, that it has been begotten by both does not diminish each parent's participation in the child's generation.

In making room for God in the common good by way of analogy, Aquinas not only establishes the relationship between God and human flourishing in the polity, but he also applies the notion of the common good to other groups, such as the family. Moreover, he provides us with the basic analytical concepts to understand how different kinds of parts - the formal and the material, the actual and the potential - are integrated into the common good. Thus, although a non-theistic person may find the relationship between God and his personal flourishing to be irrelevant, he may nonetheless still benefit from the analysis of how the different analogous parts of flourishing cohere with each other. These analytical categories introduced by Aquinas would allow us later to speak of the common good of the firm.

\section{Catholic Social Teaching and the Historically Attainable Common Good}

A third source for the common good is CST, of which it forms a core principle, together with subsidiarity, solidarity and the dignity of the human being as imago Dei (God's likeness) (Pontifical Council for Justice and Peace, 2004: 160; henceforth CSDC). ${ }^{1}$ These principles are tightly interrelated in a doctrinal unity that orients human action in politics, economics, law and other aspects of social life.

Perhaps the greatest contribution of CST to the common good is historical awareness. This feature could be detected in many ways. Firstly, in the recognition of the different expressions of evolving social life, "from the family to intermediate social groups, associations, enterprises of an economic nature, cities, regions, States, up to the community of peoples and nations" (CSDC 165). Every one of these historically evolving communities has its own common good, "a constitutive element of its significance and the authentic reason for its very existence" (CSDC 165); and the common good of the lower levels are oriented to the superior ones. The relationships among these communities are subject to at least two forces: solidarity, which is a "horizontal force" among communities of equal or similar structures, such as between two independent States; and subsidiarity, which is a "vertical force" among 
communities that are hierarchically related, such as cities or regions, on the one hand, and the State to which they belong.

Secondly, CST states that "the demands of the common good are dependent on the social conditions of each historical period" (CSDC 166). We see this, for instance, in the recognition of the fundamental rights of the person, such as the provision of basic goods and services of food, housing, work, education and so forth. It cannot be otherwise, since the protection and promotion of these rights depends on the resources available. These resources vary greatly with the level of development of a community in every historical period. Inasmuch as the levels of development can never be absolute nor resources unlimited, no human right could be fully guaranteed. That's why in a subsistence economy, for instance, it would be impossible to guarantee children's rights to education. Learning a trade or a craft is precisely the kind of education available then, not formal classroom learning. The bearing of this principle on the issue of child labor as an unfair business practice, for example, cannot be underestimated.

But even if absolute levels of development were attained and resources were superabundant, we should not neglect the role virtues play beyond upholding rights. Virtues make up for what rights, which focus on minimums, are unable to achieve. However, this limitation of rights should not stop us from improving the conditions for the common good, for "the whole of humanity and for future generations also" (CSDC 166). Thus, historical awareness of the common good provides us with a justification for corporate sustainability policies, for instance.

Essentially, the historical awareness of the common good in CST develops from intuitions already found in Aristotle and Aquinas. Recall that for Aristotle, the common good is not a universal Platonic idea, but a concrete reality that changes with time and place. And since the common good is contingent with time and place, it cannot be determined once and for all. Thus, we are constantly required to engage in dialogue, deliberation and joint action. As we have seen above, CST highlights the practical, sociohistorical and dialogic or discursive nature of the common good.

On the other hand, Aquinas's analogical and metaphysical treatment of the common good sheds light on CST's definitional attempt at the common good which "stems from the dignity, unity and equality of all people" as "the sum total of social conditions which allow people, either as groups or as individuals, to reach their fulfillment more fully and more easily" (CSDC 164). To which analogue of the common good in Aquinas does this correspond?

Surely, not to God, because God cannot be the "sum total of social conditions." Could the definition in CSDC 164 then be about eudaimonia? We argue that it is, to the extent that these "conditions" are not taken in isolation but related to the "fulfillment" of the people themselves. We claim this because the "conditions" are in potency with respect to "fulfillment," which is their act, end and perfection, the political common good or eudaimonia.

Inasmuch as the good lies primarily in the "fulfillment" (act) rather than in the "conditions" (potency), perhaps a better account of the common good is: "the good of all people and of the whole person" (CSDC 165). The common good here refers to the end state or perfection of the whole human being and of all people. This may 
be interpreted "aggregatively" — a member of society could only reach flourishing to the extent every other member also does - until the state of affairs is reached in which the entire political community is flourishing (Murphy, 2006: 63-64). Once achieved, the common good becomes indivisible. The common good is not only indivisible, objectively speaking, but also from the viewpoint of agents or subjects, since they could only achieve it through joint effort. Responsibility over the common good falls on all members of society: no one is exempt and each is expected to contribute according to his possibilities (CSDC 167), seeking the good of others as his own.

Let us return to the common good in CSDC 164, which insists on "the sum total of conditions," later clarified not as "the simple sum of the particular goods of each subject of a social entity," but a "sum" nonetheless. This makes sense if human flourishing is viewed as an "integral whole" composed of "potential parts" or "material conditions" (Aquinas's bona communia). Conditions are "potential parts" because they are not yet the common good, but only allow it to be reached. For instance, adequate material goods do not guarantee the common good, although they are a prerequisite. And the notion of "adequate material goods" corresponds to the sum total of factors or conditions such as food, drink, clothing, shelter and so forth.

\section{The Rejection of the Common Good in the Liberal Enlightenment}

Having presented our reading of the political common good inscribed within the Aristotelian, Thomistic and CST traditions, we shall briefly explore reasons for its disappearance from most of current social thinking. Our purpose here is not so much to convince or persuade followers of the liberal enlightenment to embrace the common good as to identify the main elements in their "tradition" that are incompatible with theory we propose.

The rejection of the common good is characteristic not only of a particular strand of economic liberalism which Hayek represents, but also of the whole postEnlightenment philosophy (MacIntyre, 1988). The "common good" is, for some, a mere ruse to advance a totalitarian agenda and trample on individual rights; while others hold that in an multicultural global society, such universal principle could no longer be defended (Downing \& Thigpen, 1993; Keys, 2006: 5-8). Thus, the "common good" - like "natural law" — has become a code word signifying a brand of ethics and politics inspired in Aristotelian-Thomistic tradition and the moral teaching of the Catholic Church (Benestad, 1985; Benestad, 1986; Kelly, 1995; Morse \& McNamara, 2009; Nitsch, 2005; Pines, 1988; Sulmasy, 2001; Wilbur, 1988). This disqualifies the common good from demanding rational allegiance, it is thought.

The difficulty in accepting the common good could be traced, in first place, to the dominant individualistic view of the human person. The human being so conceived is said to be already fully constituted as an individual, even before forming part of any group. For liberals in the Lockean tradition, a human being lacks an intrinsic social dimension in the original, albeit hypothetical "state of nature"; he only acquires this accidentally when, motivated by self-interest, he enters into the "social contract." For other liberals, as those belonging to the Austrian tradition, the passage to the 
social state occurs through catallaxy, the spontaneous, non-directed movement of individual freedom toward an order, akin to the emergence of the market (Hayek, 1976: 108-09). Regardless of the mechanism of passage to the social state, there is nothing "common," nothing that can be shared in these individuals' self-interests, which respond to private, non-communicable versions of utility or pleasure that are often incompatible. These self-interests should not even be called "goods," because they entail no perfection, but only the satisfaction of inclinations or desires. "Goods" are mostly understood like cakes or pies, where the portion allotted to one necessarily decreases as the number of people who get a piece increases. This corresponds to a largely materialistic conception of goods where rivalrous and exclusionary consumption is the rule. And although some may argue that liberal individualistic market societies "increase the size of the pie for everyone" or "produce the tide that lifts all boats," this does not at all guarantee that each receives his fair share. Increases in GDP do not by themselves automatically reduce inequality nor lead to a just distribution. So long as individualism and self-interest are rampant, it could very well be the case that the increases achieved in wealth disproportionately accrue to those who already held an advantageous position in the first place, with hardly any trickle down effect. In lieu of a common good, politics should pursue distributive justice alone, the observance of formal rules of collective engagement or procedures based on the rights that individual rational beings freely choose for themselves (Laczniak \& Murphy, 2008; Rawls, 1976).

We must also acknowledge the use of the term "common good" by civic republicanism and explain how we differ. Following Fort, by "civic republicanism" we understand a "politics of citizenship focused upon the common good-a good beyond narrowly construed self-interest" (Fort, 1999: 393). It is a political theory that seeks to transform a free-standing, unencumbered individual into a committed citizen whose good is inextricably tied up with that of the community. In other words, civic republicanism starts with an individual who is co-opted through contractarian means to a good beyond self-interest. Already we find here a major divergence in the concession, albeit methodological, to the individual or "first man." As mentioned earlier, in the interpretive tradition we follow, such an individual or "first man" is a mere abstraction, because all human beings are, by nature, from the very beginning of their existence, social and political. Therefore, the issue at hand is not how such an individual could be convinced through a "social contract" that it is in his interest to seek a good that is ultimately common. Rather, we should realize that there is no such individual or "first man," but only human beings who are simultaneously individual and relational already. What behooves us then is to help them realize that to pursue their own exclusive interest is self-defeating, precisely because of the starting point of their social or political nature.

Moreover, certain strands of civic republicanism, as those championed by Michelman (1988) and Sunstein (1988), understand the common good at its core-again in the words of Fort - as a "deliberative political structure in which the discussion of the good itself becomes the defining feature of politics" (Fort, 1999: 396). It is a "procedural commitment to rational discussion via "dialogical structures"” (Fort, 1999: 397). Religion plays no role in this deliberation and mediating institutions- 
similar to what we shall later on call "intermediate associations" - have a minimal say. In the school of thought to which we subscribe, a robust and substantive version of the common good is proffered, instead of a merely procedural one, at the same time that the irreplaceable value of dialogue is maintained. The role of religion is definitely acknowledged, as well as that of God, and not only as an impersonal, moral and unifying force, as civic republicans are wont to affirm (Fort, 1999: 393-94). And regarding the civic republicans' "mediating institutions," among which we could include firms, they are a sine qua non condition for achieving the political common good. In this respect, our position is closer to that advanced by Fort, together with scholars such as Macey (1988) and Epstein (1988), when they point out to these "missing elements" in their critique.

Hence, although the common good may also form part of civic republican conceptual currency, we attach to it a different meaning, derived from a distinct set of presuppositions.

\section{THE COMMON GOOD OF THE FIRM AND ITS RELATION TO THE COMMON GOOD OF THE POLITICAL COMMUNITY}

We are certainly not the first to suggest a common good theory of the firm linked to the common good of the political community. We think, however, that most previous attempts have failed to articulate clearly and precisely what a common good theory of the firm means. Instead, they have left the meaning implicit, construed it too loosely or merely hovered above it. For instance, without actually defining the common good of the firm, Mahon and McGowan (1991), Badaracco (1996) and Migué (2005) suggest its relation to corporate social responsibility; Spence and Schmidpeter (2003), to social capital; and Jones and Thompson (1984), to a specific orientation in regulation and decision-making policies. Equally vague is the position adopted by Atkinson (2004) and Daly and Cobb (1999-2001), for whom the common good of the firm simply has to do with taking an interdisciplinary approach to business, management and economics.

It is not enough for a robust common good theory of the firm to simply mention the common good. Based on our understanding of the Aristotelian, Thomistic and CST traditions just outlined, at least three conditions may be required. Firstly, it should demonstrate a fair understanding of the common good of the political community (Aristotle). Only then could a convincing account of the common good of the firm be derived by analogy (Aquinas), in second place. This entails identifying the locus and purpose of the firm in the overall context of society, aside from specifying how the good of the firm is indeed common to all the parties involved (participation). Thirdly, this theory should explain how the common good of the firm can be integrated into the common good of the political community, mainly through subsidiarity and solidarity (CST). We hope to have satisfied the first condition in the preceding sections and we shall now deal with the next two. 


\section{The Firm as an Artificial and Imperfect Society}

A general consensus exists regarding the community-relatedness of Aristotelian business ethics. For Solomon, "the corporation is first of all a community"; and even as individuals, "we find our identities and meanings only within communities, . . a at work in a company or an institution" (Solomon, 1992: 326). Koehn concurs, saying that "the larger environment affects people's self-perceptions, choices and actions," and that ethical judgment "must therefore be considered against the larger political backdrop" (Koehn 1995: 538). Hartman, for his part, extends the Aristotelian intuition that "politics is the culmination of ethics" to organization theory, granted that today, organizations can well be "the primary form of association and identification": in the best of cases, "good corporations mold good people" (Hartman, 2008: 261). However, we cannot deny the fact that there are at least two different communities involved, the firm and the political community. In what follows, we shall distinguish and at the same time connect the two, by means of a pair of Aristotelian categories, that of "natural/artificial" and "perfect/imperfect" communities, which have hardly received any attention for this purpose.

Let us begin by situating the firm within the polis. Because of its end or purpose, Aristotle considers the polis a "natural" and "perfect" society. Like families and villages, the polis is a "natural" society, originating from an innate tendency in human beings (Pltcs 1252b). "Natural" means a community to which all people, by nature or by necessity, belong. Families are necessary for the satisfaction of daily needs or survival, whereas villages, understood as collections of families, take care of the living requirements beyond the day to day. Human social instinct, however, can be completely developed only within the polis, the adequate context for eudaimonia or the flourishing to which we aspire. A "perfect society" therefore signifies one that contains all the elements needed to fulfill its end. Thus, the polis is "a community of families and aggregations of families [i.e., villages] in well-being, for the sake of a perfect and self-sufficing life [i.e., eudaimonia]" (Pltcs 1280b). Only the polis is "perfect" among "natural" societies because it alone is "self-sufficing," able to supply the needs of an entire life for its flourishing.

Although Aristotle does not mention firms in the Politics, there are allusions to them in the "family connections, brotherhoods, common sacrifices and amusements" (Pltcs 1280b) that draw human beings together. Hence, in contrast to the political community, we can describe the firm or business organization as an "artificial" and "imperfect" society. The firm is an "artificial" society because it does not arise directly from human nature in the same necessary way that families or political communities do. Rather, firms are constituted from the voluntary bonds of "friendship" or association that develop among citizens for mutual advantage (Smith, 1999: 628-31). They are "imperfect" societies because they are not self-sufficing; instead, they depend on families and the polity. Therefore, businesses are examples of "intermediate bodies or associations" situated between families and the polis. They are not meant to replace the family in the provision of daily needs, nor the polis as the locus of full flourishing. Like other intermediate bodies, their purpose is to supply some specific means or elements for the good life (Pltcs 1280b). 
At this stage, the difference between our "artificial" and "imperfect" intermediate societies, on the one hand, and the "mediating institutions" of the civic republican tradition (Fort, 1999: 395), on the other, becomes clear. Civic republicanism seems to focus mainly on size, such that families, neighborhoods and voluntary associations such as smaller firms are grouped together under "mediating institutions," while large megastructures such as nation-States and multinational corporations are excluded. From our perspective, regardless of size, firms will always be "intermediate associations" because of the locus they occupy between families and the polity and their particular function. Although they both share a socializing function, "artificial" and "imperfect" societies take into account the necessity and self-sufficiency of communities in a manner that "mediating institutions" do not.

\section{The Firm as an Intermediate Body Seeking an Economic End}

Among intermediate bodies, there are some that pursue economic ends. This economic focus characterizes businesses and distinguishes them from other intermediate groups such as churches, professional colleges, sports associations, neighborhood councils, cultural clubs and the like. Firms are intermediate bodies seeking primarily economic goals.

As Solomon reminds us, Aristotle was by and large the first economist (Solomon, 1992: 321). In his discussion of the economy, Aristotle distinguishes between household management (economy proper) and wealth-getting or chrematistics (Pltcs 1253b). Household management seems to refer mainly to the administration, use or consumption of resources in that basic unit of society which is the family, while chrematistics, to the production, acquisition or provision of the material means for the family's well-being. In both household management and chrematistics, Aristotle differentiates between a natural and a non-natural form.

Household management or economy refers to the use of property. In this, Aristotle speaks of a natural or proper and a non-natural or improper use. Take, for instance, a pair of sandals or shoes. If worn as protection for one's feet, one makes a proper use of them, but if used as tokens for exchange, one makes an improper use or an abuse (Pltcs 1257a). This distinction is, of course, based on the belief that everything has its own nature, purpose or end, including artifacts such as sandals. The proper use of a material thing, in accordance with its nature or purpose, acknowledges a "limit" that renders the activity honorable; its improper use or abuse, on the other hand, ignores the limit set by its own nature and purpose, transforming the activity into something censurable. Possibly the best known example illustrating this unnatural use of material things in Aristotle is "usury, which makes a gain out of money itself. . . . For money was intended to be used in exchange, but not to increase at interest" (Pltcs 1258b). Thus, until the modern age and the development of a capitalist economy, the practice of usury - the improper use of money to earn interest and not in exchange for other goods, which is its proper use- was always seen as a manifestation of the vice of avarice (Solomon, 1992: 321).

In wealth-getting or producing (chrematistics), Aristotle maintains the difference between the natural and the non-natural sorts. Natural chrematistics pertains 
to the provision of "such things necessary to life, and useful for the community of the family or State" (Pltcs 1256b), while non-natural chrematistics, to "riches and property [which] have no limit" (Pltcs 1267a). For non-natural chrematistics, think of the production of olive oil in the Mediterranean countries of the European Union in recent years, for example. No one would doubt of its benefits for human consumption, but EU policies concerning national quotas and protectionism - the "Comprehensive Agricultural Policy" (CAP) — have perverted production in such a way that growers are actually paid to uproot olive trees because of "excess production." Sensible limits to production have not been respected and, instead, have been transgressed, in such a manner that people are rewarded no longer for cultivating but for destroying olive groves. The tremendous waste of resources and market distortions this generates is obvious.

Natural wealth-producing is based on the belief that true riches, the property needed for a good life is limited. Beyond a certain quantity, the accumulation of material things becomes more of an obstacle than a help for flourishing. This Aristotelian intuition has been empirically verified in joint studies by welfare economists and hedonic psychologists in the new field of behavioral economics. Their research shows, for example, that an increase in income or wealth does not necessarily translate into a proportionate increase in happiness or welfare, understood as individual subjective well-being, as neoclassical economic principles would predict (Easterlin's paradox) (Easterlin, 1974). Past a certain level of income per capita of relative affluence, there seems to be a decreasing marginal utility for each additional unit of income earned. Moreover, in certain countries, those who earn the highest income even experience less happiness or individual subjective well-being than the income level immediately below (Frey \& Stutzer, 2002: 83). Both findings seem to support Aristotle's belief in a natural limit to wealth-producing or chrematistics. This Aristotelian insight is especially relevant in thinking about worker compensation, for instance. It explains the limits of income in motivating workers from the viewpoint of their own well-being. For non-natural wealth-producing, however, more is always better, for no limit is recognized. Again, given the primitive stage of the economy during Aristotle's time, non-natural wealth-producing for him largely meant engaging in retail trade, which allows an almost limitless accumulation or hoarding of money (Pltcs 1257b). The equivalent, modern expression of non-natural chrematistics is the much contested neoclassical economic principle that more income means an expanded opportunity set, and therefore, all things being equal, greater happiness or subjective well-being for the individual. This ultimately justifies the vice of avarice.

The difference between the natural and the non-natural in the production (chrematistics) and the use of wealth (economy proper) depends more on the dispositions of human beings than on the amount of things themselves that they produce or consume (Pltcs 1257b-1258a). Vices in the form of unbridled desires lead human beings to non-natural forms of producing and using material possessions. Their search for happiness then becomes self-defeating; not because of the material objects in themselves but because of the vice of avarice. On this particular note, modern happiness studies once more shed light by pointing to the negative effects of adaptation (Brickman \& Campbell, 1971). It so happens that we immediately get used to the pleasures 
and satisfactions of the material things that we crave for, such that they no longer contribute in boosting our overall happiness level. Rather, we often get ourselves into some sort of "hedonic treadmill" in which we increasingly have to run faster or consume more material goods, only to find ourselves stuck in the same place.

Within this framework, the generic purpose of firms may be defined as the nonnatural production or chrematistics of material goods. "Non-natural" here signifies that production goes beyond the capabilities of the family. When a family produces for its own consumption, it is not, strictly speaking, acting as a firm. Firms produce beyond what its members need in order to sell the excess in the market. But even then, a limit or measure has to be introduced, to avoid this productive activity from degenerating into a vice. There are two related sources of this limit in Aristotle, an immediate one, arising from the use or consumption (economy proper) of the material objects produced, and a mediate one, deriving from considerations regarding human flourishing in the polity. The question on the limit is not how many units of a given product should a firm produce in order to, for example, maximize profit, but for its members to achieve flourishing. Rather than with absolute or cardinal numbers, these limits are determined by a person's virtue, inasmuch as virtue is a necessary condition for flourishing.

As wealth-producing institutions, businesses are subject directly to economy proper or the administration and use of material goods. Consumption is more proper to individuals, families, governments and society as a whole. (Although firms also administer and use resources, their end is not consumption, but production.) Returning to the case of the European olive oil producers, they should target their output based on estimates of market demand, rather than on the subsidies they hope to receive from the European Union. The economic activity of use and consumption, in turn, should be carried out under the guidance of ethics and the virtues. A properly functioning economy in terms of production and consumption facilitates the practice of virtues by promoting favorable material conditions for them, and the virtues, in turn, ensure the proper production and use of material objects with a view to human flourishing, which is the ultimate goal of politics. The idea of the market or capitalist economy as a school for virtues (doux commerce) or, on the contrary, destructive of the moral basis of society as formulated, among others, by Hirschman (1982) has received extensive comment from organizational science literature, particularly Positive Organizational Scholarship (Cameron, 2003). Its ambivalent nature seems to imply that it is not the market itself that is enabling or disabling of virtue. Rather, the issue is whether "productive practices 'are in good order.' This depends both on the nature of work in a particular organization and on the larger macrocultural context" (Weaver, 2006: 357).

From an originally Aristotelian perspective adopted by both Aquinas and CST, the limit to a firm's production also comes indirectly from the conditions its constituents themselves establish with a view to eudaimonia, the good life or their own flourishing within the political community. Let us consider the case of an automobile factory, a great majority of whose workers reside in the same area where the plant is located. From the viewpoint of abstract market forces, we could assume that the factory would produce more cars and increase profits if, for example, its workers 
did not have days off or management did not bother to take care of the environment. But since health and a sustainable environment are values workers wish to preserve with a view to their own flourishing, they themselves should ideally impose limits to their production activities accordingly. Considerations arising from eudaimonia or flourishing in the political community set by virtue, therefore, indirectly provide a limit or measure of production in the car factory. These limitations coming from the proper consumption or use (economy) of material objects with respect to $\mathrm{eu}$ daimonia are the missing elements in the previous examples of over-production of olive oil and the accumulation of "excess" or "useless income."

Before closing this section, we need to say a few words regarding the need for intermediate associations. Although businesses are intermediate groups founded on voluntary and contingent associations, they are nevertheless vital to the good life. Flourishing would not be possible with the structures of families and the polis alone. A dense web of intermediate associations is also essential. Although no particular representative of an intermediate group or firm — such as "Acme \& Co." - is by itself necessary, the bread-making function it performs, for instance, could be. In this sense business organizations may be considered necessary. It is not so much any specific intermediate body, but intermediate bodies in general that matter for the flourishing of the political community.

It is within this hierarchy of institutions that the role of firms can finally be ascertained. This is because "the end of the state is the good life, and these [i.e., family connections, brotherhoods, common sacrifices and amusements, and by extension, firms] are the means towards it" (Pltcs 1280b). Firms are intermediate bodies dedicated to the non-natural production or chrematistics of material things, widely construed. Their activity, however, has to be subject, in first place, to the limits imposed by economy proper, which refers to the use or administration of such resources, and ultimately, to the bounds marked by the good life or eudamonia in the polity. The economic ends that business corporations seek are means to the political end of the poleis. The production of goods and services by businesses, therefore, is not self-justifying; but desirable only insofar as it contributes, in the final instance, to a flourishing life in the State.

\section{The Common Good of the Firm}

Participatory Productive Work

After identifying the locus and function of the firm within the political community, we can now determine its generic common good as the production of goods and services in which human beings participate through work. From an Aristotelian viewpoint, this is the good of the firm as an intermediate association and of each of its constituents. Insofar as the firm achieves this, it fulfils its purpose: it becomes a "good firm," one that is well-governed and that makes its members good. In the same way that citizens participate in the common good of the polis by exercising citizenship, the members of the firm participate in its common good through work.

This idea of the embeddedness of the human good, firstly, in the firm as an intermediate institution, and secondly, within the wider political community, such 
that there need not be conflict and antagonism between the two, but harmony and integration, is very similar to the view expressed by Solomon. He denounced the "schism" commonly introduced between business and the rest of one's life, when for Aristotle, they were "supposed to fit together in a coherent whole" (Solomon, 1992: 322). What's more, Solomon continues, "[a]ccording to Aristotle, one has to think of oneself as a member of the larger community, the Polis, and strive to excel, to bring out what was best in ourselves and our shared enterprise. What is best in us - our virtues - are in turn defined by that larger community, and there is therefore no ultimate split" (Solomon, 1992: 322). We extend this idea by advancing work in common, insofar as it provides an opportunity for developing the virtues, as the activity that enables the link between the of good of the firm and the good of the polity.

Let us now recall Aquinas's analogy between God, as the extrinsic, ontological and contemplative common good, and flourishing or eudaimonia, as the intrinsic, social and practical common good. Borrowing from this Thomistic perspective, the common good of the firm may be described - like eudaimonia for the polity- as intrinsic, social and practical. "Practical" because it refers to work, an activity to be performed, not just an object of speculation; "social" because work in common depends on the effort of a community, acting in coordination or in unison; and "intrinsic" because such participatory work is essential to the firm and cannot exist independently of it. If one were capable, by himself, of manufacturing a car, there would be no need, perhaps, of constituting a car manufacturing firm. But since that is practically impossible, at least on a large scale, due to limitations of time, financial resources, specialized talent, and so forth, people interested in doing so associate themselves into a corporation. The pooling together of people and resources is, above all, for the purpose of productive work that cannot be carried out except in a participatory manner. Work in common then becomes the reason for being of the firm, what brings together all the people and resources involved in the production process; it is the end that they all share in common.

Once more, drawing inspiration from Aquinas, we could describe the common good of the firm as an "integral whole" consisting of "formal" and "actual" parts, on the one hand, and "material" and "potential" parts, on the other. Workers as firm members are "formal" and "actual" parts because as free, intelligent and unique actors, their particular contribution to the common productive process cannot, to a significant extent, be replaced by the efforts of others. The use of Jews as slave labor in Nazi Germany factories clearly violates this condition, for instance. This is another way of saying that, in a sense, none of the workers in a firm that has reached its common good is expendable, and that the common productive process and its results would not be the same without every one of them. Each worker makes a difference to the whole. And as for the "material" and "potential" parts of the common good of the firm, they refer to the sum total of nonpersonal conditions, resources, instruments and means that make participatory work possible. Unlike the workers, financial capital or equipment, for instance, can easily be substituted in their contribution to the productive process by any similar amount of money or machinery. But this doesn't mean that they are any less necessary for the common 
good of the firm understood as participatory work, since certainly, this could not take place without them. The common good of the firm requires just the right people and just the right productive resources.

The common good of the firm does not relate, at first hand, to the goods and services produced in themselves. It does not lie primarily in things, but in their production by a group. Work in common, then, is the reason people come together to form the firm. Certainly, their activity does not take place in a void and a whole lot of material resources are needed. But people share more directly in the work itself than in the products that come from this work. For instance, maintenance personnel at a university do not deliver lectures, which is the primary service the university delivers, but they participate in the collective effort that allows the university through its professors to teach. Teaching is directly incumbent only upon professors and not on the maintenance personnel. Participatory work as the common good of the firm does not require that everyone does the same thing, but that there be a unity of end or purpose. Similarly, in a car manufacturing plant, although only assembly line workers may be said to engage directly in making the product, nonetheless, without the contribution of the work carried out by those in the finance department, for example, vehicles would not be produced. This is what we mean when we say that a firm's members participate more in the work in common as its common good than in the goods or services in themselves that the firm produces.

We emphasize production instead of the goods or services that result from that production because the common good of the firm has to be an activity or practice: work in common. (Analogously, eudaimonia or the flourishing in which the members of a polity participate is also an activity or practice.) Work consists in a purposive and free human act or "voluntary act" (NE 1111a), that is, one arising from the will and endowed with an "intention" or a formal knowledge of its end or aim. ("Voluntary acts" may be distinguished, on the one hand, from the "acts of man," which are the biological functions the human organism carries out without the conscious intervention of the will or the intellect, and the "involuntary acts," which are those performed against one's will or under coercion and those which entail defects in the intention or under ignorance.) Work designates that class of human or "voluntary acts" which are at the same time productive actions (NE 1139a-b). This means that work changes or transforms objects, thereby introducing certain novelty in the world. Work also differs from theory, speculation or abstract thought which simply describes, mirrors or reflects what is found in reality without changing it. In summary, work is something that we perform, and not only something that we think about. Our performance engages both our will and intellect while it changes or transforms concrete material realities, producing something that at first wasn't there, or something that was there but differently.

The Prevalence of Praxis over Poiesis

Work is a sort of transformative activity, and transformative activities are generally of two kinds: making (poiesis) or doing (praxis) (Pltcs 1254a). Whenever human beings act on matter, two different results can be expected. One is objective, existing independently from the agent and is externally observable. The other is subjec- 
tive, inhering in the agent himself and inseparable from him. Despite not being directly observable, the subjective result nevertheless has certain consequences in the agent's actions. In the case of the assembly line worker, the objective result is the manufactured car itself, whereas for the university professor, it would be the lectures he delivers. The subjective results would be the manual or mental skills, the moral excellences or virtues and the meanings that each worker develops while performing his function. The car factory worker who strives to do his work with perfection and attention to detail gains in the virtue of industriousness, while the university professor who perseveres in study and quality research advances in the virtue of diligence.

For Aristotle, examples of "making" would be the crafts and the fine arts (NE 1174a). What is important in these cases is the external object itself, as a work of art or craft, with the skill of the artist or artisan only coming in second. On the contrary, if the activity centers on the subjective result, such as when Athenian gentlemen engage in joint action to achieve eudaimonia or flourishing, we call it "doing." It is an immanent or reflexive activity, originating from the agent and ending in the agent himself, not in an external object. In doing, the human being is both the agent and the patient or result of production. Doing, therefore, is a process of "self-production," where man becomes maker (homo faber) of himself, in terms of acquired characteristics. The main result of "doing" is not an artifact, but an operative habit or virtue that the doer acquires. And in acquiring the virtues or good habits, "self-production" becomes at the same time "self-perfection." While "making" is guided by skills of craftsmanship or the fine arts, "doing" is guided by the virtue of prudence, practical reasoning or practical wisdom.

Making and doing are inseparable dimensions in any form of work. In principle, one could put a greater emphasis on the external result (making) than on the internal (doing). For Aristotle, this is the case of the productive class. Not being citizens, the members of the productive class participate very limitedly in the political common good. This, however, would be inconsistent with CST, which grants primacy to the internal or subjective dimension of work over the external or objective dimension (CSDC 270-71; John Paul II, 1981: 6). For Aristotle, this could only hold for the elite, citizens engaged in leisure, democratic deliberation and contemplation. For CST, on the other hand, work is not a mere commodity or factor of production, but a means for self-perfection for everyone. Human beings are more important than the things they produce. And although in their work, they also develop craftsmanship and the fine arts, these are secondary to the moral virtues acquired. Whereas for Aristotle, therefore, work belongs to the realm of poiesis or making, for Aquinas and CST, the conceptualization of work changes such that it is assimilated into a form of praxis or doing.

Ensuring the prevalence of internal goods or the subjective dimension of work over external goods or the objective dimension is also for Moore-in his MacIntyrean interpretation of Aristotle- the "fundamental challenge" that corporations face in avoiding "corruption" (Moore, 2005: 661). Following MacIntyre (1985: 188-89), Moore speaks of "goods internal to practice," "internal goods" or "goods of excellence" as equivalents of what we call in CST the "subjective dimension or 
result" of work, and of "goods external to practice," "external goods" or "goods of effectiveness" as corresponding to the "objective dimension or result" of work. Moore (2005: 660) cites as examples of "internal goods" those that are "generally derivable from the exercise of the virtues in search for excellence within the context of a particular practice," such as loving relationships, playing or listening to music or intellectual stimulation, and of "external goods," "prestige, status or money, which can be achieved in a variety of alternative ways not linked to any particular practice." Similarly, for "practices," Moore takes MacIntyre's definition, as "any coherent and complex form of socially established cooperative human activity" (MacIntyre, 1985: 187), and for "institutions," some form of human community that houses practices and are "characteristically and necessarily concerned with ... external goods" (MacIntyre, 1985: 194). Therefore, work (e.g., the retailing function), especially if considered from its subjective angle (praxis or doing), would be some sort of "practice," and the firm or business corporation, a kind of "institution." On MacIntyre's — and Moore's — understanding, however, institutions are necessarily corrupt and corrupting of practices, insofar as they subvert the proper order of goods, giving precedence to external goods of effectiveness over internal goods of excellence. In other words, institutions tend to view work from its objective angle (poiesis or making), focusing on external goods. Although intended as a criticism particularly of modern industrial or capitalist business organizations, a broader applicability is generally implied.

We disagree with MacIntyre and Moore regarding the inherently corrupt and corrupting nature of institutions in general and of firms in particular. At least, we have found no basis for adopting such a stand in our reading of Aristotle's Politics as developed in the previous sections, and much less in the texts from Aquinas and CST. It would be difficult to hold simultaneously, on the one hand, that human beings, because of their social nature, necessarily belong and live in institutions, and on the other, that these institutions are always corrupt. Moreover, as MacIntyre and Moore themselves take pains in affirming, there are no practices without institutions nor institutions without practices. Therefore, if institutions were necessarily corrupt, to some extent, it would not even be possible for there to be practices since, also by MacIntyre and Moore's definition, these always seem to be "virtuous," that is, they put internal goods of excellence before external goods of effectiveness.

Participatory Work and the Virtues

Once this crucial difference with MacIntyre and Moore regarding the ethical neutrality of both practices (work) and institutions (firms) has been acknowledged, we find no further trouble in agreeing with Moore's proposal on how the "virtuous corporation" could come about. A "virtuous corporation," one that has achieved its common good, could be characterized in several ways. In it the internal goods, such as "the enjoyment of the exercise of practical skills, the stimulation that the competitive situation affords, pride in accomplishment and the personal dignity that derives from a job well done" (Moore, 2005: 660) prevail over the pursuit of external goods, such as profits or reputation. This is, of course, the outcome of a constant struggle in which all the members of the firm, but especially those in positions of 
authority and power, cannot afford to let down their guard. In another account, we could say that a "virtuous corporation" is one that has reached and maintained that delicate balance between internal and external goods. This equilibrium requires a sufficient amount of external goods which, after all, are also genuinely goods, to allow the firm as a whole and its individual members to rightly pursue and advance in the internal goods. The mutually sustaining or reinforcing character of both types of goods should not be overlooked. And a third one is by suggesting that, in the "excellent corporation," the virtues are practiced not only at the personal level, but also, and jointly, as in a biconditional relation, at the institutional or firm level, in terms of "corporate character" (Moore, 2005: 663-64). Personal virtues facilitate institutional or corporate virtues in the same way that institutional or corporate virtues facilitate personal virtues. Participatory work affords one with a privileged opportunity to seek excellence, exercise practical judgment and strengthen integrity together with others.

Work is not only an opportunity to avoid idleness and subsequent vices. Neither is it just a condition that allows one to practice the cardinal and theological virtues later or in other life spheres, as Alford and Naughton (2001: 215-22) seem to imply. All the virtues can and should be lived in and through work itself. If work is truly well done, it becomes an occasion for contemplation, which is in some sense the highest of all virtues. For Aquinas and CST, this entails doing one's work ultimately for love of God. This is Aquinas and CST's response to that longing which Aristotle so pointedly formulated in his ethics.

To recapitulate, the common good of the firm is the work in common that allows human beings not only to produce goods and services (the objective dimension), but more importantly, to develop technical or artistic skills and intellectual and moral virtues (the subjective dimension). In business, entrepreneurial initiative, creativity and cooperation deserve special mention among the virtues (CSDC 336). Entrepreneurial initiative is not just waiting for things to happen, but taking the lead in identifying a genuine human need and seeking to remedy it. Creativity means, above all, exercising one's mental capacities in proposing solutions that are novel and unique, apart from being effective. Cooperativeness indicates the ability to work with others toward a common goal that cannot be reached individually. These are goods internal to particular practices found in business institutions.

How can participatory work as the common good of the firm help in acquiring and developing the virtues? We should first of all clarify what the virtues are, since they are often cast in misleading terms when differentiated from the other major ethical schools. According to this conventional account, virtue ethics emphasizes the character traits of the actor or agent, while deontological ethics focuses on the act itself and utilitarian ethics, on the results or outcomes. As Koehn has reminded us, both the act and its outcomes are as important as the character of the agent himself, since this develops precisely from the performance of certain actions as its most significant—albeit internal—result (Koehn, 1995: 533-34). What's more, no true description of a virtuous act can be given without looking into the thought processes, the intention and the desire, the practical reasoning somehow manifested in the character of the agent, acting within particular circumstances and bringing 
about certain consequences. For as Wright and Goodstein (2007) argue, character comprises individual qualities — although applicable by analogy to organizations as well- that direct the pursuit of personal and societal goods. Hartman expresses this same thought when he strongly argues against the entrenched dichotomy between the normative and the empirical or descriptive, also known as the "separation thesis," in ethics and decision making in general (Hartman, 2008).

There are several coincidences among Aristotelian business ethicists in their characterization of the virtues. Virtues speak of "excellences," of doing what is best for human beings (Solomon, 1992: 327) and seeking what is outstanding in friendly competition (Koehn, 1995: 537). Virtues also point to right practical judgment or phronesis, which includes right perception and deliberation, and sensitiveness to the particulars of one's identity, roles and situation (Solomon, 1992: 327-29). This feature may also be explained as a habitual conformity between right thinking and right desire ultimately shown in practical reasoning (Koehn, 1995: 536) or the harmony among rationality, emotions and intuitions in decisions and actions (Hartman, 2008: 257). A third trait refers to an integrity or wholeness in one's life, such that one's practices, roles, duties and responsibilities seamlessly come together (Solomon, 1992: 328-29) and a continuity or identity is preserved between one's past and future (Koehn, 1995: 536; Hartman, 2006: 72).

All of these dimensions of the virtues may be enhanced (or hindered) by the participatory work carried out in the firm. As Solomon (1992: 335) remarks, since business is above all a social activity involving other people, Aristotelian virtues are also business virtues. Moreover, "while business life has its specific goals and distinctive practices and people in business have their particular concerns, loyalties, roles and responsibilities, there is no 'business world' apart from the people who work in business and the integrity of those people determines the integrity of the organization as well as vice versa" (Solomon, 1992: 338). Moore, for his part, has identified various components of a virtuous "corporate character," some "major," such as the sustenance of a practice and the pursuit of its corresponding excellence, and some "minor," such as a "power-balanced structure" and the implementation of systems and processes that fight bias and encourage questioning (Moore, 2005: 676). And lastly, for Hartman, "corporate culture, as well as structures and systems, can be deployed to encourage and accommodate good character" (Hartman, 2006: 72). He particularly advocates a careful choice in the firm one works for, given the occurrence of a form of "adaptive preference formation": although the right corporate culture may not be a sufficient condition for personal virtue, nonetheless it surely is a necessary one (Hartman, 2006: 79).

Work in a firm also serves as an occasion for meaningful exchange, relationship and encounter among human beings. Unfortunately, we cannot at present go in depth in the empirical, sociohistorical and conceptual research concerning "meaningful work" (Ciulla, 2000), which looks into, for example, how certain features of job design, performance and outcomes help satisfy a worker's needs and deepest longings. Nonetheless, it is this intrinsic social dimension of work (CSDC 273) that allows it to be a locus of meaning which human beings can share. 
Participation in the Common Good of the Firm and Justice

Through work, a firm's members take part in the different goods, both material (products, profits) and immaterial (virtues, skills, meaning), that their joint effort creates. This participation through work is both a duty and a right for a firm's members. It is a duty because every human being is expected to contribute to the economic, cultural, political and social life (CSDC 189); and a right because work enables human beings to share not only in profits, but also in management and ownership (CSDC 281). Thus workers are able to employ and develop, besides their physical strength, their mental faculties as well. Full participation in the material and immaterial goods that a firm produces is, of course, more of a goal or objective than a reality oftentimes.

Participation in the common good of the firm —of which profits form part- is not limited to shareholders, as the financial theory of the firm suggests (Friedman, 1970), but also extends to other stakeholders (Freeman, 1984). Shareholders participate because their financial resources, representing capitalized work, is used by the firm and this entitles them to part of the firm's eventual profits. But at the same time, they can also participate in the immaterial dimension of the common good of the firm because their investment decision in itself has a moral bearing and as such could help or hinder the development of their own virtue. Imagine an investor who decides to put his money with a microlending institution in a developing country, out of a sense of altruism, solidarity or charity, instead of purchasing US Treasury bills, which despite the lower interest are certainly a lot safer. We could go on tracing the participation of each stakeholder group through work: employees, customers, suppliers, competitors and so forth (Sison, 2008: 86-93). For instance, clients could closely engage with the firm in product design or promotion through customization, and different suppliers and even competitors could band together in a supply chain management initiative that guards against unfair labor practices and environmental degradation. Different stakeholders can participate in different ways and at different levels in the common good of the firm, but the possibility of taking part in both the material and immaterial dimensions are always open to them. There is a hierarchy, however, to be observed among stakeholders: persons take precedence over non-persons such as the environment, and direct stakeholders over indirect stakeholders. This is in consonance with the principle that work be considered a form of praxis, where the subjective, immaterial dimension precedes the objective, material dimension. From the perspective of participation, management workers who also own equity stakes are probably the best positioned to contribute, achieve and benefit from the common good of the firm. Because of equity ownership, they participate in the financial resources the firm needs, because of their work, they participate in the production process, and because of their specific management roles, they participate in organizational governance. The need for participation in corporate governance is a consequence of the fact that the common good is not an abstract, Platonic idea to be contemplated by some autocratic visionary. Instead, it is a practical matter to be decided on by a firm's members through joint deliberation or dialogue. 
As we can see from the above, effective and rightful participation in the common good of the firm is never automatic or mechanical. Insofar as it involves multiple actors or stakeholders bound together in some sort of a community, it requires the virtue of justice, which is the social virtue par excellence, in its distributive and contributive forms. Distributive justice refers to the duties and obligations of the whole (the firm) to its parts (workers and other stakeholders), while contributive justice, the duties and obligations of the parts to the whole. For example, distributive justice demands paying a just wage-in CST, a "living wage," that takes into account not only the individual worker's needs, but those of his dependents as well-while contributive justice requires that workers dedicate their best efforts to production, taking care of the firm's resources at the same time. Duties and obligations always have corresponding rights; so the enjoyment of certain rights entails the fulfillment of duties and obligations. Yet to conceive the welter of relationships in the firm exclusively in terms of rights and duties would lead to an impoverished outlook. For justice, law and rights only prescribe minimums, not the excellence or perfection at which virtue aims.

Recently, Hsieh has advocated certain institutional reforms in the modern production system to better align it with the demands of liberal egalitarian or Rawlsian justice (Hsieh, 2008). Among them are the guarantees for meaningful work at the individual worker level, worker participation in the governance of firms at the organizational level and democratic participation in the control of the means of production at the societal level. Despite the divergence in backgrounds, Rawlsian versus Aristotelian-Thomistic, the coincidence at least in the letter of our proposals is quite remarkable indeed. We both agree in the importance of participation in itself, at work and in institutions, almost independently of its impact on productive efficiency, which is, perhaps, the only justification acceptable to modern industrial capitalism. Hsieh grounds this on the liberal egalitarian ideal of distributive justice, while we base our claim on the Aristotelian-Thomistic notion of the common good, which includes, but is not limited to distributive justice alone, as indicated above. Contributive justice is equally important.

Finally, for a firm to fulfill its common good, the goods and services produced should be truly useful and satisfy the legitimate needs and wants of people ("real goods"). ${ }^{2}$ On this account, not only pornography and illegal drugs, but also pet rocks ("apparent goods"), for instance, ought to be disqualified. Production must also make the best use of scarce resources and be efficient. The EU farm subsidies mentioned earlier blatantly violate this principle. Only when these conditions are observed would businesses comply with their social function of contributing to the wider common good, by observing economic discipline and upholding values (CSDC 338).

In this section, we have defined the common good of the firm, participatory work, and explained its constituents in comparison with the common good of the polity. We have insisted on its nature as an activity or praxis. Because of this, the common good of the firm is also open to the development of virtues and the forging of meaning. In the end, we explored the different ways of participating in the common good of the firm in accordance with a two-fold justice, distributive and contributive. 


\section{The Structure of the Common Good of the Firm and Subsidiarity}

In speaking of the political common good within the context of CST and Thomistic traditions, we believe it is helpful to think in terms of Millán Puelles's (1971) two-fold explanation of the common good, distinguishing its "essence," which corresponds to what we have already explained in previous sections, from its hierarchical and teleological "structure," which Millán Puelles explains in terms of three different levels. This latter feature provides us with further indications on how the different elements comprising the common good are connected and how difficulties in the pursuit of lower level goods are overcome by elevation, as it were, focusing on the higher order goods. It also warns and dissuades us from obsessively seeking lower order goods to the extent that we are distracted and ultimately forget about the higher level goods to which they are directed and in which they fulfill their meaning. We shall extend Millán Puelles's analysis here from the common good of society to the common good of the firm.

These levels are, from the lowest to the highest, material well-being, peace and concord, and cultural values. The first, material well-being, should not be confused with the necessary material goods in themselves. Rather, it is the satisfaction that derives from participating in such goods. Material goods are external means that lead to satisfaction or well-being, but satisfaction itself is not material. It is necessary for the political common good that each member of society have sufficient material means for a decent life. This is not simply a matter of meeting the biological requirements for survival, but of making social life and acts of virtue possible (Leo XIII, 1891: 25).

The second level of peace and concord does not depend exclusively on material goods, although it demands a minimum of them. There could be an abundance of material goods without well-being, due to unjust distribution, for example. Just distribution, then, is another requisite for peace and concord as pointedly illustrated by the "ultimatum game" (Güth, Schmittberger \& Schwarze, 1982). It is not sufficient for players to be simply better off, acquiring more resources or utilities; it is equally expedient that these resources be distributed fairly. Peace is defined by St. Augustine as the "tranquility in order" (Augustine of Hippo, 1964: 1. 19, c. 13), while concord is described by Aquinas as the condition when two men freely agree to something that is good for both (Aquinas, 2006: q. 29, a. 3, ad 1). In the same way that well-being is a condition for peace and concord, these, in turn, are indispensable for human beings to cultivate superior cultural values.

Cultural values, which represent the third level, include a variety of technical, artistic, intellectual, ethical and spiritual goods among others. Millán Puelles calls them "cultural" insofar as they are neither "natural" nor "innate" but freely sought or acquired by individuals. Moreover, they seem to be the goals or objectives for which peace and concord (the second level) would be desirable as conditions. Although they may not present themselves with the same urgency as the two previous levels, they are even more important. We ought to seek peace and concord, more than for their impact in our material well-being, for their help in allowing us to participate in the cultural values that satisfy our nobler aspirations. 
This three-level structure of the political common good, somewhat reminiscent of Maslow's (1943) pyramid of needs and motivations, could analogously be applied to the common good of the firm. The first level, material well-being, would correspond to profits, financial capital, equipment and other material conditions that affect a firm's economic viability and sustainability. Profits may indicate how well a firm is doing, the surplus value it creates, but their generation per se cannot be the purpose of a firm — as Friedman (1970) contends - nor exhaust its common good (John Paul II, 1991: 43). We would also have to examine how profits are produced and to what end they are destined, whether these are in accordance with the laws and in a manner that promotes virtue (Benedict XVI, 2009: 21). Profits are legitimate business objectives and should not be shunned. As seen earlier, they are materialpotential parts of the common good of the firm, "foundational" means that support superior ends of "excellence" (Alford \& Naughton, 2001: 42-51).

The second level of peace and concord would correspond to good governance or management practices, to the right rules, procedures and structures institutionalized in the firm. As Moore (2005: 676) suggested, these refer to the balance of power and the encouragement of enquiry in developing the right "corporate character." We could also add policies on equal opportunity employment, performance and meritbased promotion and compensation, continuing formation programs, transparency and fairness in the resolution of labor disputes, and so forth. Worker well-being does not only depend on adequate material resources and pay, but also on the compliance with the rules of distributive justice, for example. No matter how much a worker is paid, if he thinks he is not being treated fairly in comparison to his equals, he will not achieve well-being nor job satisfaction. Neither will there be genuine peace and concord in the organization.

And thirdly, the cultural values encompass not only different forms of technical expertise and artistic skills, but also ethical and spiritual meaning and values, including openness to God or contemplation. Recent movements which promote spirituality in the workplace (Miller, 2007) attest to the need of workers to be respected and valued integrally, without having to renounce important aspects or dimensions of their identity. They struggle to bring their spiritual and religious beliefs to bear on their work and at the workplace, as a source of ethical guidance and purpose, thus making a positive contribution to their organizations. This, of course, represents a huge challenge, not only on the multicultural, global front, but also - at least, for public institutions - on the issue of the separation between church and State which is fundamental to modern, secular democracies. But it is a challenge that could no longer be ignored.

Managers should keep an eye on all three levels of the firm's common good. Each of these levels integrate an organic whole, such that if any were lacking, the other two would be unable to fulfill their function. Moreover, there is a positive feedback among all three. A teleological hierarchy ought to be observed, nonetheless, such that the lower level is at the service of the higher. For instance, it would be wrong to pay attention to governance (second level) only when certain profit objectives (first level) have been surpassed, or to consider the cultural development of workers (third level) only when there are no labor conflicts (second level). Profits should 
be pursued never in themselves alone, but with a view to the superior levels, and frequently, the key to hitting profit targets lies in fair compensation schemes (second level) and providing adequate training (third level). Often, solutions to problems in one level are to be found in the superior ones, given the positive feedback among them. Recall the previous example concerning an automobile factory. In the interest of the common good, profits (first level) ought not to be sought in themselves to the detriment of family life and cultural pursuits (third level), and oftentimes, fair wage practices (second level) are the best guarantee of both material well-being and personal growth outside of the work domain.

The common good of the firm is, however, a particular good with regard to the common good of the larger society. The appropriate relationship between the State and an intermediate group as the firm is one of "subsidiarity" (CSDC 186-87). States and firms have their own objectives and spheres of action; they owe each other respect, notwithstanding the superiority of the State. In accordance with subsidiarity is a double dimension to the State's role with regard to firms, on the basis of which we find justification for its intervention. As the superior-order society, the State should positively help, support and assist businesses. And put negatively, the State should refrain from replacing or absorbing businesses and appropriating their functions.

The State represents the highest political authority. It is needed to render available the necessary material, cultural, moral and spiritual goods to citizens (CSDC 168). It is also entrusted with harmonizing different particular interests within the framework of justice (CSDC 169). But this does not mean, on the grounds of subsidiarity, that the State will directly provide the aforementioned goods nor immediately intervene as the sole authority when conflicts occur. Rather, the State should respect and encourage private and lower level initiatives to respond to these needs-which often turn out to be more effective - and step in only when these prove insufficient. For the State itself is but a historical expression of underlying civil society, and its goal limited to the "historically attainable common good" (CSDC 168). Thus the role of the State is duly relativized by a correct understanding of the common good. The State cannot and should not directly take care of everything.

The positive aspect of subsidiarity requires that States encourage firms as private initiatives, contributing to a healthy pluralism and diversity in society. The State should delegate to these groups, in closer contact with the needs and desires of people, tasks they would carry out better. For example, it would be hard to justify why States should be developing and commercializing word-processing software. By fostering the development of intermediate groups such as business organizations, the State makes more efficient use of resources, focusing on public services such as defense, foreign relations or the administration of justice. The negative aspect of subsidiarity guards against statism in its many forms (excessive centralization, the usurpation of decision-making powers, bureaucratization, shirking by government personnel, welfarism and paternalism). Subsidiarity provides the most effective guard against a self-serving State, ensuring that it serve citizens and intermediate institutions instead.

Finally, although subsidiarity has been formulated primarily to describe the relationship between the State and lower order bodies, it could also be applied to 
the links between different hierarchical orders in any organization. For instance, the decision to waive transaction fees for a client normally should not be taken by someone from a bank's headquarters, but by someone in the branch where the account is held, such as the manager, or better still, the teller.

We find ourselves before two different communities, each with its own common good. Firms are artificial and imperfect intermediate associations seeking an economic goal, the non-natural production of material means (chrematistics). As such, they are subordinated to the political community, the natural and perfect society in which flourishing (eudaimonia) is achieved. The common good of the firm, the production of goods and services in which human beings participate through work, is a particular good or means with respect to the ultimate common good of the political community, eudaimonia. The subordination of the firm to the State ought to be governed by subsidiarity. The similarity between subsidiarity and the Japanese notion of kyosei, "living and working together for the common good," is indeed remarkable and warrants further exploration (Wokutch \& Shepard, 1999).

\section{Other Versions of the Common Good of the Firm in the Aristotelian, Thomistic, and CST Traditions}

What we have just outlined represents one among several possible accounts of the common good of the firm belonging to the Aristotelian, Thomistic and CST traditions, widely construed. Others could be gleaned, in various degrees of elaboration and completeness, from selected business, management and economics sources. What sets our own reading apart from others, however, lies mainly in the way we seek to integrate the common good of the political community with the common good of the firm through a double relationship of subsidiarity and solidarity.

Velasquez (1992) elucidates the common good — citing its Catholic affiliationin national, international and global contexts, but not the common good of the firm. Velasquez's denial, on revised Hobbesian-realist grounds, that international business has a moral obligation to contribute to the international common good so long as there is competition and a lack of an international enforcer casts suspicion on his understanding of the common good. For although the common good could only be achieved through the concerted effort of all, the duty to work toward it is, in a sense, independent of what other agents do. Agents should not condition their cooperation toward the common good, for fear of free-loading, on others taking the first step. That would be the perfect excuse for the common good never to materialize. Moreover, contribution to the common good cannot depend exclusively on coercion by an international authority, in a manner similar to the Hobbesian Leviathan (Velasquez, 1992: 28). That would go against the principle of subsidiarity and make the common good seem more like the outcome of compulsion rather than choice. Rather, the pursuit of the common good should arise freely at the same time from the people themselves and the lower level communities they form. Doubts regarding Velasquez's reading are further aggravated when he equates the common good to something like Rawls's principles of justice, "general conditions that are .. . equally to everyone's advantage" (Velasquez, 1992: 27-29). Koslowski speaks 
of the common good of the firm, but only from a very limited dimension, as the fiduciary obligations of managers (duty to good faith, the duty to loyalty toward the firm, the duty of care and prudence, and the duty of disclosure) (Koslowski, 2006: 72-75). Argandoña (1998) seeks to clarify the common good, both for the political community and the firm, but is distracted by an intent to transform it into an ethical foundation for stakeholder theory. That different authors disagree on the ethical foundation of stakeholder theory does not mean it lacks one. And a careful analysis reveals stakeholder theory's Kantian provenance, contractualist bias and emphasis on rights and duties. How that, especially an overbearing "rights talk," could be made compatible with an intrinsically social view of the human being and a conception of the human good in keeping with the Aristotelian-Thomistic tradition would prove quite problematic, pace Freeman's (2007) recent claims. Melé takes pains as well in deciphering the common good for various human groups; but like many others, he stops at its understanding as a host of conditions (Melé, 2009: 235-36). As we have shown, this may not be incorrect, but it is incomplete, for the good is found more in fulfillment than in conditions, although the two are indeed inseparable. Furthermore, although Melé may be right in advocating the "common good principle" as a managerial driver, he does not go into detail how other stakeholders of the firm participate in this common good (Melé, 2009: 238-39).

Therefore, in contrast with the three-fold criterion we have stated, we find that Velasquez speaks of a common good of the political community, but not of the firm. Koslowski, Argandoña, and Melé do refer to the common good of the firm. But Koslowski, without disclosing its relation to the political common good; Argandoña, striving to render it compatible with individualist and contractualist assumptions inconsistent with common good thinking; and Melé, unable to go beyond the "sum total of conditions," which is only the common good in potency, to actual "flourishing" or "fulfillment," which is the common good in act, and without explaining how different stakeholders can participate in such a common good.

By contrast Kennedy (2006: 51-62) offers a rich understanding of the common good broadly in line with the tradition we have described. He refers to the contribution of the firm to the common good in general, when it augments the wealth-producing capacity of society and offers better goods and services to address material needs (Kennedy, 2007: 180-81), and in particular, when it develops a culture of collaboration and competition, a stable financial infrastructure, a system of laws and regulations and the effective application of technology (Kennedy, 2006: 76-77). But again, Kennedy never speaks of the common good of the firm as such. He simply states that, to be "morally legitimate," the common goods of "specialized associations" such as business firms "must be true human goods (and not merely apparent goods, such as vengeance or pornography) and they must be pursued by morally sound means (so a criminal organization might pursue real goods but do so by immoral means)" (Kennedy, 2007: 177). Moreover, he insists that "specialized associations" are not legitimated by their contributions to the common good of the political community directly, but by the private goods they make possible for their members (Kennedy, 2006: 68). This is quite odd, because the reason for being of "specialized associations" is the service they render or contribute to the 
political community, and one would that think this applies transitively to the goods they produce. In other words, pace Kennedy, the private ownership and enjoyment of the good produced by firms does not at all detract from the firms' contribution to the political common good and their legitimacy. Instead, it is precisely through the production of these private goods that firms contribute to the common good of the polity and legitimize their existence.

Kennedy's distinction between real and apparent goods echoes that of Alford and Naughton (2001: 60-64). Alford and Naughton also differentiate between excellent (human development) and foundational goods (profits, capital, technology), distributed through participation and allocation, respectively (Alford \& Naughton, 2001: 42-51). For these authors, the purpose of the firm is the production of real goods, with excellent goods given priority over foundational goods. We cannot agree more with the hierarchy that Alford and Naughton propose. Nonetheless, we'd like to extend their argument by explicating how the members of the firm participate in its specific common good and by expanding the scope of the virtues from the cardinal virtues to those associated with work. The virtues of work well done should also be linked somehow to the ultimate good of contemplation, in the Thomistic sense. (Remember that Aristotle had reserved contemplation exclusively for the elite of the polis.)

\section{CONCLUSION}

Almost a decade ago, Solomon (1992: 318-20) voiced a complaint regarding the conception of business ethics, the relevance of which has not completely waned. For some - the holders of the macro view-business ethics is in truth a philosophy of economics, a social-political philosophy which focuses on economic justice. But business students, executives and corporations often find this inaccessible and inapplicable, so others - the holders of the micro view-go to the other extreme of ignoring theories and systems and concerning themselves instead with the motives and consequences of individual behavior. However, there are problems here also, since no mechanical algorithm for ethical problem-solving can be offered (Koehn, 1995: 534) and often, the principles derived from the study of individual conduct cannot be applied straightforwardly (Hartman, 2006: 75). Solomon, in fact, is happy with neither, despite recognizing the merits of each, and advocates in their place a "molar" or "integral" view of business ethics, one centering on the individual within the corporation. He holds that individuals do not exist in a social vacuum, that they carry out their business roles in and through firms as the "basic unit of understanding," and that business organizations, in turn, are defined by their roles and responsibilities in the larger political community. Our endeavor throughout this essay has been to extend this integral, molar perspective and to fill in possible gaps through a theory of the common good.

The common good acts as an integrative force on several different levels. We have defined the common good of the firm as the participatory work in which all its different members engage, insofar as this provides them firstly, with an opportunity to acquire and develop skills, virtues and meaning (subjective dimension), and secondly, 
with a chance to efficiently or profitably produce goods and services that society needs (objective dimension). This is what unites the various stakeholders in the firm, thus constituting a community. But the firm represents only one kind of intermediate association, that which seeks to produce material wealth or resources beyond the capacities of individuals and their families (non-natural chrematistics). Therefore, the common good of the firm ought to be embedded within a wider common good, that of the political community. The common good of the political community consists in the flourishing (eudaimonia) that each of its citizens or members can achieve, only to the extent that all the other citizens or members achieve it also. As we have seen, this political common good is composed of formal-actual parts, which are irreplaceable, and material-potential parts, which can be substituted by others of a similar nature and quantity. Through its objective dimension, the common good of the firm supplies these material-potential parts of the political common good. The relationship between the common good of the firm and the political common good is best expressed through the principle of subsidiarity. By subsidiarity CST understands that the political community represented by the State should not take over the functions that lower level institutions such as firms are better prepared to fulfill. Rather, States should encourage and promote private initiatives and step in only as a subsidium or help when these falter or are insufficient. The protagonism, therefore, should lie with these lower-level communities.

Besides integrating the different members of the firm and integrating the firm within the political community, the common good allows for a third, more anthropological level of integration. This has partly been referred to in the subjective dimension of the common good of the firm, the acquisition of skills, virtues and meaning at work, and in the focal point of the political common good or eudaimonia. It lies in the recognition that our highest ambition as human beings (eudaimonia) cannot be achieved individually but only in concert with our fellows and that work is a necessary means to attain it. But work has to be considered not only in its poiesis aspect, directed toward the production of external, material objects, but above all, in its praxis aspect, centering on the qualitative changes it effects in the subject or worker. Work, therefore, is a privileged occasion to develop and to practice all the different excellences or virtues, including theoria or contemplation, which has the divine, transcendent or spiritual for its object. The virtues, particularly those of character, together with different classifications of goods have been the focus, so far, of most Aristotelian business ethics scholarship. For our part, we have striven to underscore how work virtues form a privileged part of the common good and how they effect the integration of the different aspects of human identity: desires, motivations, feelings, reasonings, judgments, actions, habits, characters, roles, situations, organizational cultures and the various "life spheres" of family, work, church and civil society through time. As part of the common good, virtues are like the glue that keeps our identity whole and intact.

People do not work for money alone, which is but one of its results as a form of poiesis, but above all, for the opportunity that work provides for self-realization, as an instance of praxis. This is true for everyone, regardless of his station in life. And given the social nature of human beings, there is also a need for participatory 
work in intermediate associations called firms, through which they contribute to their ultimate flourishing in the political community.

For the common good theory of the firm to be further developed, several things still have to be done. We can only outline them here. The first is to explain more fully how each of the firm's constituents - employees, customers, suppliers, competitors and so forth - can participate in the common good of work, not only in its objective dimension, but more importantly, in its subjective, virtue dimension. In this article we hope to have established that such two-fold participation is essential and necessary for a common good theory of the firm, but we have not had the chance to explore further how exactly this can be done for each stakeholder group. Nevertheless, several different formulas that encourage participation in the ownership and governance of firms come to mind. For instance, the organizing of cooperatives, the institutionalization of workers' councils and even two-tier boards where employee representatives sit at the supervisory board (Aufsichsrat) as in the German corporate tradition, the implementation of ESOPs made available not only to executives but to all of a firm's workers, and so forth, would certainly empower workers who would gain, apart from "sweat equity," financial and "mental" or "managerial equity" as well. In the case of customers or clients, initiatives in coproduction (Ostrom, 1990) would similarly provide them with a chance not only to provide labor, but also to influence the design or delivery of products to better suit their particular needs, enhancing satisfaction and strengthening loyalty to that specific corporate community.

Secondly, each firm member's participation in work demands a thorough account of how they can live the different excellences or virtues (subjective dimension), while improving the quality of products, increasing profits and so on (objective dimension). This delves into the conceptual and empirical links between the different virtues at work and their results or outcomes, both at the personal and the institutional or corporate levels. Further work in this area would require examining how the notion of virtue in the Aristotelian, Thomistic and CST traditions melds or not with the related concepts of virtue in Positive Organizational Scholarship (Cameron, 2003), Positive Organizational Behavior (Luthans, 2002), Organizational Citizenship Behavior (Organ, Podsakoff \& MacKenzie, 2006) and Organizational or Corporate Virtue and Character in mainstream Business Ethics. Modern scholarship tends to be more empirical, descriptive and quantitative, even taking in inputs from cognitive neuroscience, and thus more management-friendly. It could then prove a handy complement to the older tradition of virtue and common good thinking that is more normative. For instance, within the context of Modern Happiness Studies, one could investigate how personal virtues, either as traits or behaviors, are related to domain-relative flourishing in the workplace and to absolute flourishing pertaining to one's life as a whole (Warr, 2007). The common good feature of happiness or flourishing has already been sufficiently explained.

And lastly, an operational managerial paradigm has to be designed based on the new anthropological, political, economic and ethical premises that the common good supplies. Foreseeably, the outcomes of the aforementioned study of the links between the older and the newer schools of virtue would yield powerful insights 
into how common good thinking could be put into practice. Inevitably, in due course, certain challenges to the other, more established theories of the firm, such as the neoclassical and the (neo-)institutional models which arose from the grounds of the liberal Enlightenment would be made. Their assumptions of individualism and understanding of the good as mere preference-satisfaction will be questioned. In order to be successful, however, it would not be sufficient for this novel paradigm to seek a retrospective, "prelapsarian" justification. But instead, it should be sociologically, historically and technologically nuanced, ready to address the different challenges of highly fragmented and at the same time tightly networked pre-industrial, industrial and post-industrial societies, hardly capable of a cogent discussion, much less a substantive agreement on moral goods. In other words, it would have to show that the common good is not only an attractive idea, but also a feasible and practical reality.

\section{NOTES}

1. Published by the Pontifical Council for Justice and Peace, the Compendium is an official statement of the Catholic Church's teaching at the highest level of authority from the perspective of Moral Theology. It is not just a compilation or summary, but a systematization of CST to date, conveniently bringing together and profusely citing all the different sources of this body of literature in a single volume.

2. For the categories of "real" or "true goods," on the one hand, and "apparent goods,"on the other, please refer to Kennedy (2007: 177). This distinction will be addressed more extensively in the subsection "Other Versions of the Common Good of the Firm in the Aristotelian, Thomistic and CST Traditions."

\section{REFERENCES}

Alford, H. J., \& Naughton, M. J. 2001. Managing as if faith mattered. Notre Dame, Ind.: University of Notre Dame Press.

Aquinas, T. 1954. De perfectione vitae spiritualis. In R. M. Spiazzi (Ed.), T. Aquinas, Opuscula theologica (vol. II). Taurini: Marietti. (English version: Procter, J. (trans.). 1950. The religious state, the episcopate and the priestly office: A translation of the minor work of the saint on the perfection of the spiritual life. Westminster, Md.: Newman.)

1962. Commentary on the Nicomachean Ethics, trans. E. L. Fortin and P. D.

O’Neill. In R. Lerner and M. Mahdi (Eds.), Medieval political philosophy. Ithaca,

N.Y.: Cornell University Press.

1993. Commentary on the Politics, trans. C. I. Litzinger. Notre Dame, Ind.: Dumb Ox Books.

2006. Summa theologiae, ed. English Province of the Order of Preachers.

Cambridge: Cambridge University Press.

Argandoña, A. 1998. The stakeholder theory and the common good. Journal of Business

Ethics, 17: 1093-1102.

Aristotle. 1985. Nicomachean Ethics, trans. T. Irwin. Indianapolis: Hackett Publishing. 1988. The Politics, ed. S. Everson. Cambridge: Cambridge University Press. 
Atkinson, R. 2004. Connecting business ethics and legal ethics for the common good: come, let us reason together. Journal of Corporation Law, 29: 470-531.

Augustine of Hippo. 1964. The city of God, trans. G. G. Walsh and D. J. Honan. Washington, D.C.: Catholic University of America Press.

Badaracco, C. H. 1996. Public opinion and corporate expression: In search of the common good. Public Relations Quarterly, 41(3): 14-19.

Benedict XVI. 2009. Encyclical Letter Caritas in veritate. http://www.vatican.va/holy_ father/benedict_xvi/encyclicals/documents/hf_ben-xvi_enc_20090629_caritas-in -veritate_en.html\#_edn8.

Benestad, J. B. 1985. Henry George and the Catholic view of morality and the common good, I: George's overall critique of Pope Leo XIII's classical encyclical 'Rerum Novarum.' American Journal of Economics \& Sociology, 44(3): 365-78.

1986. Henry George and the Catholic view of morality and the common good, II. American Journal of Economics \& Sociology, 45(1): 115-23.

Brickman, P., \& Campbell, D. T. 1971. Hedonic relativism and planning the good society. In M. H. Apley (Ed.), Adaptation-level theory: A symposium: 287-302. New York: Academic Press.

Cameron, K. S. 2003. Organizational virtuousness and performance. In K. S. Cameron, J. E. Dutton \& R. E. Quinn (Eds.), Positive organizational scholarship: 48-65. San Francisco: Berrett-Koehler Publishers, Inc.

Ciulla, J. 2000. The working life: The promise and betrayal of modern work. New York: Three Rivers Press.

Daly, H. E., \& Cobb, J. B., Jr. 1999-2001. For the common good. Journal of Business Administration \& Policy Analysis, 1999: 27-29, 2001:65-86.

de Bettignies, H. C. 2009. Can multinational corporations afford to ignore the global common good? Business \& Society Review, 114(2): 153-82.

Deissenberg, C., \& Álvarez González, F. 2002. Cheating for the common good in a macroeconomic policy game. Journal of Economic Dynamics \& Control, 26: 1457-79.

Downing, L. A., \& Thigpen, R. A. 1993. Virtue and the common good in liberal theory. Journal of Politics, 55: 1046-59.

Easterlin, R. 1974. Does economic growth improve human lot? In P. A. Davis \& M. W. Reder (Eds.), Nation and households in economic growth: Essays in honor of Moses Abromowitz. New York: Academic Press.

Epstein, R. A. 1988. Modern republicanism-Or the flight from substance. Yale Law Journal, 97: 1633-50.

Fort, T. L. 1999. The First Man and the Company Man: The common good, transcendence, and mediating institutions. American Business Law Journal, 36: 391-435.

Freeman, R. E. 1984. Strategic management: A stakeholder approach. Boston: Pitman. 2007. Managing for stakeholders. http://ssrn.com/abstract=1186402.

Frey, B. S., \& Stutzer, A. 2002. Happiness and economics: How the economy and institutions affect well-being. Princeton, N.J.: Princeton University Press. 
Friedman, M. 1970. The social responsibility of business is to increase its profits. The New York Times Magazine (13 September).

Froelich, G.1989. The equivocal status of bonum commune. The New Scholasticism, 63 (Winter): 38-57.

Güth, W., Schmittberger, R., \& Schwarze, B. 1982. An experimental analysis of ultimatum bargaining. Journal of Economic Behavior and Organization, 3(4): 367-88.

Hartman, E. M. 2006. Can we teach character? An Aristotelian answer. Academy of Management Learning \& Education, 5(1): 68-81.

. 2008. Reconciliation in business ethics. Some advice from Aristotle. Business Ethics Quarterly, 18(2): 253-65.

Hayek, F. A. 1976. Law, legislation and liberty: The mirage of social justice, vol. 2. Chicago: University of Chicago Press. 2001. The road to serfdom. London: Routledge.

Hesselbein, F. 2008. In service to the common good. Leader to Leader, 47(Winter): 4-6.

Hirschman, A. O. 1982. Rival interpretations of market society: Civilizing, destructive, or feeble?" Journal of Economic Literature, 20: 1463-84.

Holzinger, K. 2003. Common goods, matrix games and institutional response. European Journal of International Relations, 9(2): 173-212.

Hsieh, N. 2008. Survey article: Justice in production. The Journal of Political Philosophy, 16(1): 72-100.

John Paul II. 1981. Encyclical Letter Laborem exercens Acta Apostolicae Sedis, 73: 577 647. 867.

Jones, L. R., \& Thompson, F. 1984. Risks for efficiency: Comprehensive reform of direct regulation. Academy of Management Review, 9(4): 746-56.

Kelly, M. J. 1995. Vincentian dynamic: Common ground for the common good. Review of Business, 17(2): 4-9.

Kennedy, R. G. 2006. The good that business does. Grand Rapids, Mich.: Acton Institute. 2007. Business and the common good. In P. Booth (Ed.), Catholic Social Teaching and the market economy: 164-89. London: Institute of Economic Affairs.

Keys, M. M. 2006 Aquinas, Aristotle, and the promise of the common good. Cambridge: Cambridge University Press.

Koehn, D. 1995. A role for virtue ethics in the analysis of business practice. Business Ethics Quarterly, 5: 533-39.

Koslowski, P. 2006. The common good of the firm as the fiduciary duty of the manager. In G. J. Roussouw \& A. J. G. Sison (Eds.), Global perspectives on ethics of corporate governance: $67-76$. New York: Palgrave MacMillan.

Laczniak, G. R., \& Murphy, P. E. 2008. Distributive justice: Pressing questions, emerging directions, and the promise of Rawlsian analysis. Journal of Macromarketing, 28(1): 5-11.

Leo XIII. 1891. Encyclical Letter Rerum novarum. Acta Leonis XIII, 11 (1892): 97-144. 
Lewis, C. W. 2006. In pursuit of the public interest. Public Administration Review, 66: 694-701.

Lindahl, T., \& Johannesson, M. 2009. Bargaining over a common good with private information. Scandinavian Journal of Economics, 111: 547-65.

Luthans, F. 2002. Positive organizational behavior: Developing and managing psychological strengths. Academy of Management Executive, 16: 52-72.

Macey, J. R. 1988. The missing element in the republican revival. Yale Law Journal, 97: 1673-84.

Machan, T. R. 1993. Individual rights, the common good and the environment. International Journal of Social Economics, 20(9): 54-65.

MacIntyre, A. 1985. After virtue, 2nd ed. London: Duckworth.

1988. Whose justice? Which rationality? London: Duckworth.

Mahon, J. F., \& McGowan, R. A. 1991. Searching for the common good: A processoriented approach. Business Horizons, 34(4): 79-86.

Maslow, A. 1943. A theory of human motivation. Psychological Review, 50(4): 370-96.

Melé, D. 2009. Integrating personalism into virtue-based business ethics: The perrsonalist and the common good principles. Journal of Business Ethics, 88(1): 227-44.

Michelman, F. 1988. Law's republic. Yale Law Journal, 97: 1493-1537.

Migué, J. L. 2005. The economist on the common good. Fraser Forum: 24-26.

Millán Puelles, A. 1971. Bien común. Gran Enciclopedia Rialp, vol. 4: 225-30. Madrid: Ediciones Rialp.

Miller, D. W. 2007. God at work. The history and promise of the faith at work movement. Oxford: Oxford University Press.

Moore, G. 2005. Corporate character: Modern virtue ethics and the virtuous corporation. Business Ethics Quarterly, 15(4): 659-85.

Morse, S., \& McNamara, N. 2009. The universal common good: faith based partnerships and sustainable development. Sustainable Development, 17(1): 30-48.

Murphy, M. C. 2006. Natural law and jurisprudence in politics. Cambridge: Cambridge University Press.

Nitsch, T. O. 2005. Economics, social justice and the common good: Roman Catholic perspectives. International Journal of Social Economics, 32(6): 554-69.

Organ, D. W., Podsakoff, P. M., \& MacKenzie, S. B. 2006. Organizational citizenship behavior: Its nature, antecedents and consequences. London: Sage Publishers.

Ostrom, E. 1990. Governing the commons: The evolution of institutions for collective action. Cambridge: Cambridge University Press.

Pines, C. L. 1988. The bishops' dilemma with capitalism: A critical analysis. Journal of Business Ethics, 7(6): 445-52.

Pontifical Council for Justice and Peace. 2004. Compendium of the social doctrine of the Church. Rome: Libreria Editrice Vaticana.

Rawls, J. 1976. A theory of justice. Cambridge, Mass.: Harvard University Press. 
Samuelson, P. A. 1954. The pure theory of public expenditure. Review of Economics and Statistics, 36(4): 387-89.

Sison, A. J. G. 2008. Corporate governance and ethics. An Aristotelian approach. Cheltenham, UK: Edward Elgar.

Smith, M. A. 1995. Human dignity and the common good in the Aristotelian Thomistic tradition. Lewiston, N.Y.: Mellen University Press.

Smith, T. W. 1999. Aristotle on the conditions for and limits of the common good. The American Political Science Review, 93(3): 625-36.

Solomon, R. C. 1992. Corporate roles, personal virtues: An Aristotelian approach to business ethics. Business Ethics Quarterly, 2: 317-39.

Spence, L. J., \& Schmidpeter, R. 2003. SMEs, social capital and the common good. Journal of Business Ethics, 45(1/2): 93-108.

Sulmasy, D. P. 2001. Four basic notions of the common good. St. John's Law Review, 75(2): 303-10.

Sunstein, C. R. 1988. Beyond the republican revival. Yale Law Journal, 97: 1539-90.

Urban, S. 2007. Financial markets and human capital: New evaluation norms and auditing practices needed. European Business Law Review, 18(1): 167-79.

Van der Wal, Z., \& Van Hout, E. J. Th. 2009. Is public value pluralism paramount? The intrinsic multiplicity and hybridity of public values. International Journal of Public Administration, 32(3/4): 220-31.

Velasquez, M. 1992. International business, morality, and the common good. Business Ethics Quarterly, 2(1): 27-40.

Weaver, G. R. 2006. Virtue in organizations. Moral identity as a foundation for moral agency. Organization Studies, 27(3): 341-68.

Walshe, S. 2006. The primacy of the common good as the root of personal dignity in the doctrine of Saint Thomas Aquinas. Rome: Pontifical University of St. Thomas.

Warr, P. 2007. Work, happiness and unhappiness. Mahwah, N.J.: Lawrence Erlbaum Associates.

Wilbur, J. B. 1988. Self-interest and community. Journal of Business Ethics, 7(6): 453-58.

Wokutch, R. E., and Shepard, J. M. 1999. The maturing of the Japanese economy: Corporate social responsibility implications. Business Ethics Quarterly, 9(3): 527-40.

Wright T. A., \& Goodstein, J. 2007. Character is not "dead" in management research: A review of individual character and organizational-level virtue. Journal of Management, 33: 928-58. 